\title{
On Development of China's System of National Accounts and Suggestions for Improvement
}

\author{
Hu Xuemei \\ School of Statistics, Beijing Normal University, Beijing, China
}

\begin{abstract}
The release of SNA (2008) revised by the United Nations and another four international organizations caused widespread concern and in-depth study in the world. Based on the development of China's National Accounts System, the paper analyzed the gaps between China's current SNA and the latest international standards. The results show that these gaps are embodied in the institutional sector settings, the research and development expense classification, the statistical methods for employee compensation, the ownership classification, the assets classification, and the methods for the calculation of central bank's output. Finally, considering the latest provisions of SNA (2008) and the actual needs of China, the paper makes some relevant suggestions for improving these deficiencies.
\end{abstract}

Key words: SNA, GDP data, accounting table

\section{Instruction}

After the release of the System of National Accounts, 1993 (SNA1993), the global economic environment has undergone various significant changes, especially the outbreak of the international financial crisis in 2008, which all highlights some omissions and missing items in the national accounts. In order to reflect the new changes timely and accurately occurring in the economy and society, maintain SNA's advancing, and at the same time, to keep in line with other professional statistical international guidebooks, the United Nations together with other four international organizations issued the System of National Accounts, 2008 (SNA2008) based on the revision of the SNA1993 version. Compared with the SNA1993, the SNA2008 does not recommend fundamental or comprehensive changes (SNA2008, Introduction), but focuses on the updating, classifying and refining towards some basic concepts, basic categories, basic calculation methods, basic statistical indicators and so on (Research Group on "Revision of SNA and Reform of Chinese System of National Accounts", 2013).

To meet the needs of macroeconomic management and decision making, and enhance the international comparability of accounting results, China developed a set of nationally appropriate and normative national accounts, namely "China's System of National Accounts (2002)", on the basis of drawing on international SNA. However, since China is still in the period of economic transition, coupled with the presence of some actual factors, such as a short history of the national accounts, the weakness of the accounting foundation, and the blockage of data resources, the result is that when comparing China's System of National Accounts (CSNA)

Corresponding author: $\mathrm{Hu}$ Xuemei, Ph.D. Candidate, School of Statistics, Beijing Normal University, Beijing, China. E-mail: huxuemei257@163.com. 
with the latest international standard accounting system, and with the countries having developed market economy, there is still a large gap. In addition, the birth of a new version of the SNA will once again have a profound impact on the reform and develop of CSNA.

Therefore, we need to understand the current situation in the development of CSNA, and treat the newest version SNA2008 as a criteria and reference, and then analyze the gaps between the current CSNA and the SNA2008, and on this basis, to discuss the action programs and basic roadmap for the future reform and development of CSNA.

\section{Accounts and Table Settings of CSNA}

The national accounts program adopted at this stage in China has undergone continuous evolution process. Generally believed that the establishment of CSNA covers three different modes' rotation of three periods, namely: (1) from the early years of new China foundation to 1984, the Material Product System (MPS) was used; (2) from 1985 to 1992, both the MPS and SNA were used, and during this period, "China's System of National Accounts (pilot program)" was developed including the contents the MPS and the SNA, reflecting China's accounting mode's transition characteristics from the MPS to the SNA (Xianchun Xu, 2009); (3) since 1993, SNA was used, and on the basis of a major revision towards the "pilot program", the "China's System of National Accounts (2002)" was formed. Since then, China has been using SNA, and although some contents were/ will be modified, the central framework and the essence of it remain unchanged (Minxue Gao, 2013).

From the perspective of general framework, CSNA has three components, namely the basic accounting tables, national economic accounts, and subsidiary tables (see figure 1). Among them, the basic accounting tables include production accounting, input-output accounting, flow of funds accounts, balance of payments accounting, and national wealth accounting; the national accounts include general economic accounts, domestic institutional sector accounts, and foreign institutional sector accounts; and the subsidiary tables contain the physical accounting of natural resources, human resources and human capitals. In the system, the following points should be noted:

(1) Accounts are the main accounting tools, and the main medium connecting each accounting body;

(2) The basic accounting tables and the national economic accounts are both a description of the process and results of national economy operation, but they have different emphases - each basic accounting table in the former focuses on accounting for certain aspects of economic activity, and all the economic accounting tables form an organic whole, accounting for a full range of national economy; the product account, the income distribution and expenditure account, the capital account, the financial account, the balance sheet accounts and the foreign sector account in the latter constitute the entire system skeleton, reflecting the situation of production, distribution, consumption, accumulation and external trade in national economy, describing the total flow of national economy and flow of departments, and showing the physical and value flow in the circular motion of national economy.

(3) The subsidiary tables are a complement and flexible application of the core part of CSNA, and in order to satisfy the needs of a variety of data furthest, to expand and extend accounting bodies and contents from the way of data supply and presentation. 


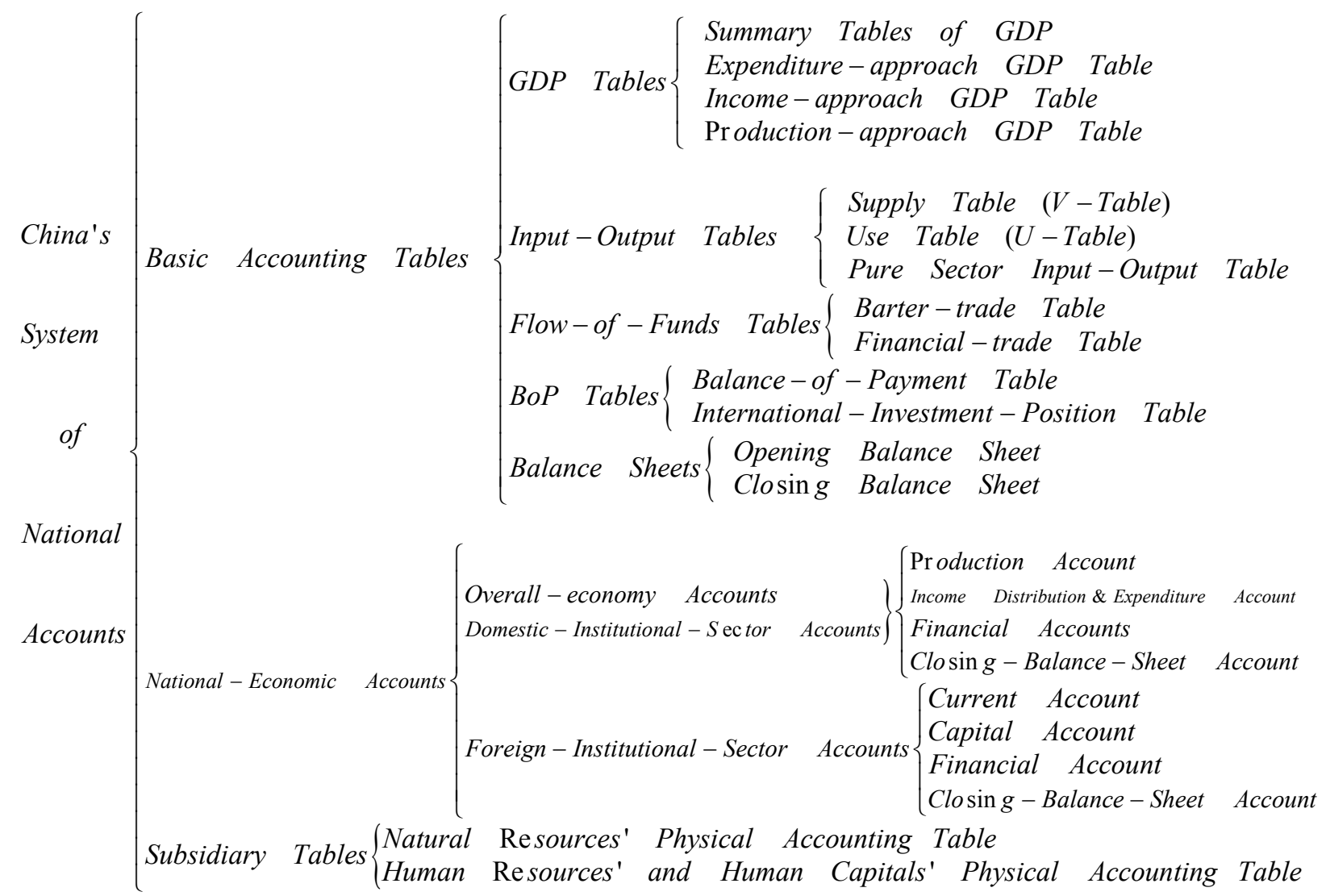

Figure 1. General Framework of CSNA ${ }^{1}$.

Overall, compared with the "pilot program" released in 1992, "China's System of National Accounts (2002)" is more rigorous in the structure, reflecting the intrinsic link among the activities of national economy; more rich in content, covering the main aspects of national economy operation in the market economy; and more scientific in its approaches, taking into account both the actual needs and the possibility of realization. However, with the continuous development and changes of economy and society, some new situations and problems keep coming in national economy, which cannot be covered in the current accounting system (such as the emergence of financial derivatives), and although some have been already included, the scope or meaning of them may be changed. So, when economic development comes to a new height, people should realize the shortcomings existing in the "China's System of National Accounts (2002)".

\section{CSNA's Gaps: A Comparative Study Based on SNA2008}

After ten years of practice and development, China's first fairly standard CSNA has made significant improvements, especially in the economic census years (e.g. 2004, 2008), but compared with the latest version of 2008SNA, there still exist many gaps.

First, in the institutional sector setting, SNA2008 divides resident units constituting the overall economy into five independent institutional sectors, namely non-financial corporation's sector, financial corporation's sector, general government sector, non-profit institutions serving households sector, and households sector.

\footnotetext{
${ }^{1}$ Figure 1 refers to Xu, Xianchun \& Zheng, Jingping (2008). The Interpretation of Main Statistical Indicators. China Statistical Press.
} 
However, in CSNA, all the resident institutional units are divided into four, namely non-financial corporation's sector, financial institutional sector, government sector, and households sector. Obviously, the non-profit institutions serving households sector doesn't be treat separately, but included in government sector with other various administrative units. In addition, CSNA is not as detailed as SNA2008 in the fine classification of the various institutional sectors.

Second, in the classification of research and development (R\&D) expenditure, SNA2008 adjusts it from the original intermediate consumption to intellectual property products under the item of fixed assets investment. That is to say, R\&D is capitalized as produced assets. The shift not only has a significant impact on the size and distribution structure of assets, also affect international competiveness due to different effects on different economies' GDP. However, China's current SNA still follows the SNA1993 approach, which not only treats it as intermediate consumption or input, but has not yet introduced the concept of intellectual property products.

Third, in the employee compensation statistics, SNA2008 puts remuneration of independent operators into mixed income, and meanwhile, because of employee stock options play an obvious effect in corporate governance, and are treated as a positive incentive mechanism for improving workers' enthusiasm in more and more units, the new international standard version promotes its integration into employee compensation statistics. Compared with 2008SNA, CSNA not only puts remuneration of independent operators into employee compensation, also has not yet established the statistical system of employee stock options.

Fourth, in the classification of ownership, SNA2008 divides it into economic ownership and legal ownership, and in most cases, the both owners are the same; if different, the new standards advocate that the related content should be recorded on the balance sheet of the economic owner, and the time of recording depends on the time of economic ownership change. Among them, the criteria of the ownership identified are: owners, who bear risks and gets benefits from transactions, have the economic ownership. Currently, in dealing with the processing trade, only the input-output table meets the new standards; and on the entrepot trade, China hasn't got the basic data required for its calculation.

Fifth, in the classification of assets, SNA2008 doesn't divide produced assets into tangible and intangible assets, and also the "intangible assets" is renamed "intellectual property product"; in addition, revises the classifications of financial and non-financial assets. That's to say, in the financial assets classification, the concept of "financial derivatives and employee stock options" is introduced, while in the non-financial assets classification, although still be divided into produced non-financial assets and non-produced non-financial assets, "fixed assets" in the former and all the items in the latter are no longer made a distinction between tangible and intangible assets. Compared with the latest international standard, there is a large gap in the current CSNA: CSNA not only fails to establish statistical systems of financial derivatives, employee stock options and other items, also doesn't put some important non-financial assets (such as valuables in produced non-financial assets, etc.) into accounting, and classifies non-financial assets roughly. In addition, China's national balance sheet is still in a trial stage, and the data has not yet announced (Monan Zhang, 2013).

Sixth, in the calculation method of central bank output, SNA2008 divides it into market output and non-market output according to nature of services; advocates that monetary policy service and regulatory services should be given more attention; implicit taxes and implicit subsidies should be introduced, and the calculation of central bank FISIM should be free from rate intervention (Research Group on "Revision of SNA and Reform of Chinese System of National Accounts", 2013). And China's current practices in the regard are: 
central bank and other bank corporate units are put together to calculate total output; moreover, market output and non-market output are divided by type of accounting system; in addition, the method for calculating FISIM is reference rate.

All of the above are the differences existing in the CSNA comparing with the international latest version of national accounts system. It should be noted that China is still in the catch-up phrase, and the capacity in terms of national accounts is relatively less. Therefore, the gaps between CSNA and SNA2008 are far more than these, such as the connotation of producer price, GDP expenditure classification, methods for calculating housing services consumed by owner occupiers and so on.

\section{Suggestions for Revising CSNA}

The facts that new trends in the development of international SNA, and developed countries continue to put the new standards into practice, pose severe challenges to China's current accounting system. What's more, China's System of National Accounts (2002) based on SNA1993 has been running in practice for over ten years, according to the above analysis, which version has lagged far behind the international new version of SNA2008. In addition, the need for diluting the traditional GDP-oriented thinking so as to keep sustainable development of China's economy also makes it necessary to accelerate the establishment of a new and suitable national economic accounting system for China, and then treat it as a measure to promote China's economy to restructure and upgrade (Monan Zhang, 2013). To this end, China should make efforts in the following areas in the future to secure the progressiveness and applicability of CSNA:

(1) Updating the basic concepts. For some concepts that have not been introduced in CSNA at present, such as "economic ownership", "financial derivatives and employee stock options", "intellectual property product" and so on, should be introduced in CSNA duly while improving relevant statistical systems; for differences in definition, coverage and other aspects, such as producer price, remuneration, range of assets, etc., should be re-defined or divided on the basis of SNA2008. Taking the producer price as an example, producer prices in CSNA excluding non-deductible VAT (value added tax) will be consistent with its connotation defined in the SNA2008.

(2) Refining the basic classifications. First, in institutional sector setting, taking into consideration of social groups or non-governmental organizations continuing to grow in recent years, and changes in relationship with government sector, as well as their non-profit production activities, so CSNA can follow the practice of SNA2008 and separate non-profit institutions serving households sector from government sector as China's fifth institutional sector. Second, in assets classification, with private lending increasingly active and increasing in size and all kinds of financial derivatives continuing to emerge in financial markets, so CSNA should revise financial assets classification, and introduce the asset item of "financial derivatives and employee stock options" duly; in non-financial assets classification, CSNA can divide it into produced assets and non-produced assets according to the formation, and cancel the argument of tangible and intangible assets.

(3) Revising calculation methods. The following items should be adjusted calculation methods: first, when calculate the expenses of R\&D, CSNA should treat it as a part of fixed capital formation, rather than being treated as intermediate inputs or consumption; second, in calculating the output of central bank, CSNA should divide it into market services and non-market services according to the nature of services, and then calculate the outputs respectively; third, in calculating the output of FISIM, CSNA should avoid the influence of interest rate on the result; fourth, when calculate the output of housing services consumed by owner occupiers, CSNA 
should take into account of the reality of the rapid development of China's real estate, and transfer the method from the original cost approach to market rent approach used in most countries.

\section{Conclusions}

System of National Accounts (SNA) as international norms and guidebook following the development of the times is the product of breeding age. China learns the advanced experience in practice actively after having realized SNA's important role playing in the world, and then develops a fairly normative and suitable for Chinese conditions' CSNA on the basis of SNA1993. However, it should be noted that despite tremendous efforts having been made in the latest CSNA, it is still some distance from the SNA, the practices of developed countries, and the requirements by macroeconomic management, civil society and international organizations (Xianchun $\mathrm{Xu}, 2009$ ). After doing a comparative study with the SNA2008, we can find that the differences are embodied in the institutional sector setting, classification of R\&D expenses, employee compensation statistics, classification of ownerships, classification of assets, as well as the calculation approaches for central bank's output. Therefore, in order to enhance CSNA's applicability and international comparability, China should improve these issues on the basis of SNA2008.

However, it should be seen that the international SNA has experienced the evolution of five versions, and each revision and republication lasts for a long time, requiring lots of human resources, material resources and financial resources. Therefore, when learning from SNA2008, China should develop an overall strategy and implementation schedule, and at the same time, list the issues that need to be revised in the form of a list, and then combining with the availability of basic data, determine the issues that should focus on and the order to solve those problems.

\section{References}

Research Group on "Revision of SNA and Reform of Chinese System of National Accounts". (2013). Revision of SNA and Reform of Chinese System of National Accounts. Statistical Research Journal (in Chinese), 12: 10-23.

Research Group on "Revision of SNA and Reform of Chinese System of National Accounts". (2013). Study on Revised Calculation Methods on Output of Central Bank in SNA and Relevant Reform in China. Statistical Research Journal (in Chinese), 10: 3-7.

United Nations and other International Organizations. (2009). System of National Accounts, 2008. National Accounts Division of National Bureau of Statistics of China and Institute of National Accounts, Renmin University of China Translation. (2012). China Statistical Press.

Xu, X. C. (2009). The Establishment, Reform, and Development of Chinese System of National Accounts. Review of Income and Wealth, 55(1): 442-465.

Gao, M. X. (2013). New Features of 2008 SNA: Some Reflections. Statistical Research Journal (in Chinese), 5: 8-16.

$\mathrm{Xu}$, X. C. and Zheng, J. P. (2008). The Interpretation of Main Statistical Indicators. China Statistical Press.

Zhang, M. N. (2013). China Needs to Establish a New System of National Accounts. China Economic Report, 9: 94-96. 